\title{
Optimal Design of Rainwater Detention System using SWMM and Linear Programing
}

\author{
Sang-Hyuk Park 1,1 , Min-Cheol Kim²,2, Seol-Hee Park 2,3 , Hyun-Dong Lee ${ }^{14,}$ \\ and Jayong $\mathrm{Koo}^{2,5}$ \\ ${ }^{1}$ Korea Institute of Civil Engineering and Building Technology, 283, Goyandae- \\ Ro Ilsanseo-Gu, Goyang-Si, Gyeonggi-Do, 411-712, Korea \\ 2 University of Seoul, Seoulsiripdae-ro 163, Dongdaemun-gu, Seoul, 130-743,
} Korea

\begin{abstract}
The purpose of this research was to make optimal design on capacity and number of multi-objective rainwater detention system that can satisfy irrigation and dimension of flood prevention as well as acquiring water source such as fire water, landscape water, and water for living in the medium and small scale basin where flood occurs frequently during focused raining due to the increase of impermeability layer. The methodology executed in this research was designed so that the construction fee and maintenance/management fee consumed in the rainwater detention system become minimized while various benefits including water and sewage cost, dam construction fee reduction, and flood damage cost reduction fee can be maximized. When considering the installation of rainwater detention system in the already developed cities or new cities, more effective design can be possible when using the same method.
\end{abstract}

Keywords: Multi-object rainwater detention system, linear programming, SWMM

\section{Introduction}

Due to the overcrowded urbanization according to the rapid economic growth, forest land and farmland are decreasing and the impermeability layer area such as sites and roads are increasing. Also, due to the abnormal climate such as global warming, localized rainfall is increasing. When the impermeability layer area is large during focused rainfall, the rain cannot penetrate into the ground leading to direct outflow into the stream current in a short period, and there may be worries where flooding can occur for the downstream areas within the city during this process(Arash, 2012).

When focused rainfall occurs during the city, there is a need for rainwater reduction system for detention and artificial penetration of rainwater. Furthermore, there is a need for technology for optimal operation. However, there are fewer areas that can install these large systems within the cities as urbanization continues, and due to the high land prices the installation becomes limited or expansion becomes difficult (Haifeng, 2012).

On the other hand, the need of substitution water resource due to lack of water around the world is being magnified, and water circulation technologies such as reusing treated sewage water and using rainwater are being developed. In this aspect, when minimizing

\footnotetext{
${ }^{1}$ Senior Researcher, Korea Institute of Civil Engineering and Building Technology (karasin811@kict.re.kr, Corresponding author)

2 Research Prof., Dept. Environmental Engineering, University of Seoul (dq3d007@nate.com )

${ }^{3}$ Master student, Dept. Environmental Engineering, University of Seoul (yssnow89@nate.com )

4 Senior Researcher Fellow, Korea Institute of Civil Engineering and Building Technology (+31-910-0297, hdlee@kict.re.kr)

5 Prof., Dept. Environmental Engineering, University of Seoul (jykoo@uos.ac.kr )
} 
flood damage of downstream areas within the city through systems that can reduce rainwater leaked to the steam current during rainfall can be achieved and when the water resource such as detention water can be reused through firewater and/or landscape water, installation and operation of these systems can be more effective.

In order to reduce such flood damage, flood should be prevented, domestic water and landscape water should be secured and optimized rain water managing system such as multi-objective rainwater detention system should satisfy both flood control and conservation (Horton, 1933; Huber and Dickinson, 1988; PGC, 1997).

Thus, to acquire substitute water resource and prevent flood damage due to rainwater, it is judged that various aspects shall be considered to install rainwater penetration system and/or rainwater detention system. Therefore, this research developed the optimal design methodology to decide the location and capacity of rainwater detention systems being installed while achieving various goals.

\section{Methodology}

This research selected optimal design methodology to decide the location and capacity for optimal installation of rainwater detention system while also achieving various purposes.

By using the SWMM model, which is the urban runoff model used in medium and small scale basins, the flooding amount and discharge were compared and analyzed by scenarios to satisfy various purposes on rainwater detention system by water rainfall.

Optimization technique was used for comparison and analysis of each scenario to minimize flood damage and reduce maintenance and management price when installing rainwater detention system. Also, multilateral aspects were considered that can reduce operation fee of surrounding infrastructure equipment due to rainwater detention system. The methodology used for optimal design of rainwater detention system in this research is shown in the procedure of Figure 1.

STEP 1(Establishing SWMM Model): This is the stage of composing sewer road by converting sewer road of target area to Auto CAD., and then re-composing the converted Auto CAD file to object of SWMM.

STEP 2 (Create Rainfall Data): Rainfall data, which is the basic data of hydrologic data selects the possible rainfall amount of the most appropriate possibility distribution by using FARD2006 program from the hourly rainfall data at the weather center.

STEP 3 (Inputting Data of SWMM Model): This is the stage of entering Watergate data such as pipe network/weather/topography data in SWMM Model. For the pipe network data, the repair check of the corresponding area was referred, and the topography data used existing land use. DEM data was used to analyze gradient, and then the basic was divided. The probability rainfall amount selected in STEP 2 used the Huff dispersion to apply the time distribution of calculated design rainfall as rainfall data.

STEP 4 (Scenario Analysis for Preparatory Location Calculation) : All the places where flood occurs due to rainfall within the research target area and the nearby manhole spot to install multi-objective rainwater detention system are overlapped to calculate preliminary candidate. Analyze flood relieving effect by scenario according to number, amount, and location of rainwater detention system, the rainwater outflow reduction system.

STEP 5 (Optimal Design of Multi-Objective Rainwater Detention System using Linear Programming) For optimal design of multi-objective rainwater detention system, this research used linear programming; for the objective function, the minimum cost of construction fee and maintenance/management fee along with the location and capacity of optimal multi-objective rainwater detention system that can achieve maximum profit for flood damage amount and water/sewage cost reduction are to be calculated. 


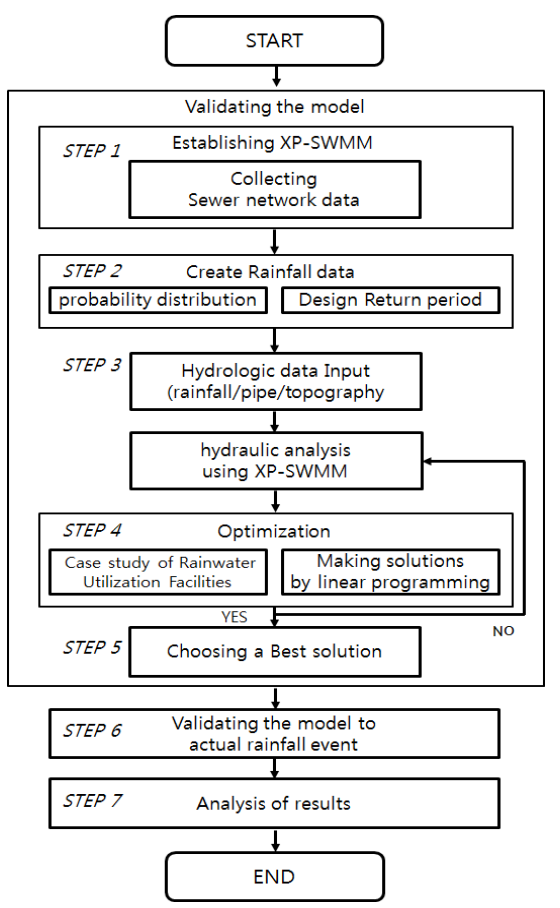

\section{Figure 1. \{SEQ Figure $\backslash \mathbb{N}\}$ Flowchart of Optimal Design Rain Detention System}

\subsection{Scenario Analysis for Preliminary Selected Area of Multi-Objective Rainwater Detention System}

When establishing rainwater balancing reservoir and exclusion plan, generally the design frequency is set to $5 \sim 10$ years, and the dam type considers stability to set design frequency to 30 50 years. This research set the reappearance frequency to $10,20,30$, and 50 years to satisfy the size for than 30 years for the size of detention system. Furthermore, the duration of rainfall was applied to probability rainfall amount of 60 minutes, 120 minutes, and 180 minutes. The applied rainfall amount is shown in Table 1.

When installing multi-objective rainwater detention system in all the small river basins of the research target basin, enough flood dissolution effect occurs, but in reality it is impossible to install rainwater detention system in all small river basins due to issues according to budget. Thus, when the number of installation of multi-objective rainwater system is limited due to the limitation of budget, this research considered the land area of the preliminary selected area, acquisition of land area, and application to install rainwater detention system around the places that flood in all rainfall under the premise of Table 2. Especially, the area possible for installation is wide as it is easy to acquire land of multiobjective detention system to select national land possible of acquiring detention storage as target.

Manhole spot that floods in rainfall and the place with national land nearby the manhole spot are overlapped to select 7 places as the possible target area for the installation of rainwater detention system, and this is shown in Figure 2. The situation of each location is shown on Table 3. Total of 5 places including S1, S2, S3, S4, and S5 were selected as the target spots for the installation of rainwater detention system nearby the manhole spot where flood occurs.

Lowland downstream area was focused to actively promote flood prevention by the developed built-up area in the research target area. The preliminary selected area of the selected multi-objective rainwater system stores rainwater at the point that becomes direct cause of flooding according to location, capacity, and number of detention system to install off-line detention system to maximize the use of land and for the flood reduction 
effect to compare and analyze flooding amount and flood dissolution about per rainfall of corresponding basin by scenario.

Table 1. Probability Rainfall per Duration - Return Period

\begin{tabular}{c|c|c|c}
\hline & \multicolumn{3}{|c}{ Probability Rainfall (mm) } \\
\hline $\begin{array}{c}\text { Return Period } \\
\text { (year) }\end{array}$ & $60 \mathrm{~min}$ & $120 \mathrm{~min}$ & $180 \mathrm{~min}$ \\
\hline 5 & 65.9 & 95.6 & 119.8 \\
\hline 10 & 77.2 & 112.3 & 142.2 \\
\hline 20 & 88.0 & 128.4 & 163.7 \\
\hline 30 & 94.3 & 137.6 & 176.1 \\
\hline
\end{tabular}

Table 2. Consideration When Deciding the Location of Rain Water Storage System

\begin{tabular}{|c|c|}
\hline Classification & Major contents \\
\hline $\begin{array}{l}\text { Consideration when } \\
\text { deciding the location }\end{array}$ & $\begin{array}{l}\text { - Area which can provide sufficient storage capacity } \\
\text { considering plottage of installation } \\
\text { - Area which has excellent reduction effect and flood } \\
\text { damage } \\
\text { reduction } \\
\text { - Area which does not have major problems for } \\
\text { construction } \\
\text { or traffic management considering local conditions }\end{array}$ \\
\hline $\begin{array}{l}\text { Excluded location for } \\
\text { installation }\end{array}$ & $\begin{array}{l}\text { - Area which is higher than ambient regions } \\
\text { - Area which has insufficient installation effect due to } \\
\text { narrow } \\
\text { basin area at the installation point } \\
\text { - Private land }\end{array}$ \\
\hline
\end{tabular}

Table 3. Status of Installable Site for Rainwater Detention System

\begin{tabular}{c|c|c|r|r|r|r|c}
\hline \multirow{2}{*}{$\begin{array}{c}\text { Cn Classificati } \\
\text { on }\end{array}$} & \multicolumn{7}{c}{ Installable site for rainwater detention system } \\
\cline { 2 - 8 } & $\mathrm{S} 1$ & $\mathrm{~S} 2$ & $\mathrm{~S} 3$ & $\mathrm{~S} 4$ & $\mathrm{~S} 5$ & $\mathrm{~S} 6$ & $\mathrm{~S} 7$ \\
\hline $\begin{array}{c}\text { Land } \\
\text { Category }\end{array}$ & $\begin{array}{c}\text { Park/B } \\
\text { uilding } \\
\text { site }\end{array}$ & $\begin{array}{c}\text { Buildi } \\
\text { ng Site }\end{array}$ & $\begin{array}{c}\mathrm{Pa} \\
\mathrm{rk}\end{array}$ & $\begin{array}{c}\text { Par } \\
\mathrm{k}\end{array}$ & $\begin{array}{c}\mathrm{Sc} \\
\text { hool }\end{array}$ & $\begin{array}{c}\text { Fores } \\
\mathrm{t} \text { land }\end{array}$ & $\begin{array}{c}\text { Road } \\
/ \\
\text { Railroad }\end{array}$ \\
\hline Area $\left(\mathrm{m}^{2}\right)$ & 2,150 & 9,000 & $\begin{array}{c}5, \\
000\end{array}$ & $\begin{array}{c}1,2 \\
00\end{array}$ & $\begin{array}{c}5,0 \\
00\end{array}$ & $\begin{array}{c}20,00 \\
0\end{array}$ & $\begin{array}{c}2,10 \\
0\end{array}$ \\
\hline
\end{tabular}

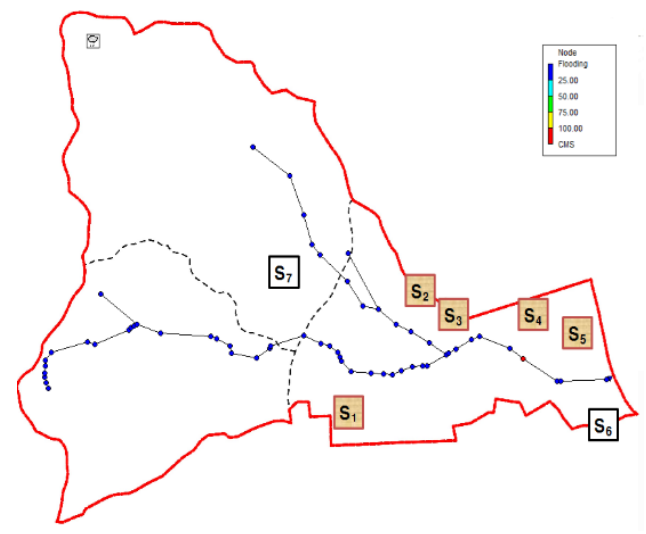

Figure 2. Selecting Installable Site for Rain Water Storage System 


\subsection{Optimal Design of Multi-Objective Rainwater Detention System Using Linear Programming}

This research uses linear programming from optimal methods to minimize the consumed cost during multi-objective rainwater detention system, and also attempted to maximize benefit. The cost and benefit calculations of rainwater detention system are as follows.

\section{(1) Rainwater Detention System Cost}

The cost of rainwater detention system is the sum of consumed construction cost during installation of rainwater detention system and the maintenance/management cost, and this is shown in Equation (1).

$$
C_{\text {total }}=\sum_{i=1}^{n} a_{i j} X_{i}+a_{2} \sum_{i=1}^{n} X_{i}
$$

(Equation 1)

Here,

$a_{i j}$ : Installation cost according to location and capacity of rainwater detention $\operatorname{system}\left(\$ / m^{3}\right)(i=1, \cdots, n, j=1, \cdots, m)$

$a_{2}$ : Maintenance/Management cost of rainwater detention system $\left(\$ / \mathrm{m}^{3}\right)$

$X_{i}$ : Capacity of rainwater detention capacity $\left(\mathrm{m}^{3}\right)$

(2) Benefit of Rainwater Detention System

Social benefit that can be acquired from the use of rainwater is the sum of construction cost reduction, support money reduction of surrounding areas of the dam, management cost reduction of surrounding areas of the dam, and flood damage amount. This is shown in Equation (2).

$$
B_{\text {total }}=b_{1} \sum_{i=1}^{n} X_{i}+b_{2} \sum_{i=1}^{n} X_{i}+b_{3} \sum_{i=1}^{n} X_{i}
$$

Here,

$$
\begin{aligned}
& b_{1}: \text { Water and sewage cost of rainwater detention system }\left(\$ / \mathrm{m}^{3}\right) \\
& b_{2}: \text { Flood damage amount of rainwater detention system }\left(\$ / \mathrm{m}^{3}\right) \\
& b_{3}: \text { Support money related to dam of rainwater detention } \operatorname{system}\left(\$ / \mathrm{m}^{3}\right) \\
& X_{i}: \text { Capacity of rainwater detention system }\left(\mathrm{m}^{3}\right)(\mathrm{i}=1, \cdots, \mathrm{n})
\end{aligned}
$$

\section{Results}

\subsection{Comparison and Analysis of Flooding Amount of Multi-Objective Rainwater Detention System Using SWMM Model}

The preliminary selected area of rainwater detention system was selected based on the national land with less consumption of budget along with manhole spots where flood occurs on all rainfall. To stimulate the flooding amount according to capacity by location of each rainwater detention system, the value of other input factors were not changed, and only the location and capacity of rainwater detention system were changed to derive the result value on the change of flooding amount.

Case 1: Non-Installation of Multi-Objective Rainwater Detention System

The reappearance frequency of before installing rainwater detention system used as criterion to compare floor amount of rainwater detention system by scenario and the flood level by duration were grasped, and the results are shown in Table 3.1. 
As a result of comparing flooding amount of 60 minutes, 120 minutes, and 180 minutes per reappearance frequency, the flooding amount was relatively high as the reappearance frequency and duration were high. The rainfall amount of when duration is 180 minutes according to the frequency of 30 and 50 years were $176.1 \mathrm{~mm}$ and $191.5 \mathrm{~mm}$, respectively.

Here, the rainfall amount was identified to be the highest at $32,280 \mathrm{~m}^{3}$ and $64,634 \mathrm{~m}^{3}$. As a result of comparing the flooding amount by reappearance frequency and duration, flooding amount of installing rainwater detention system occurred in the frequency of 10 20 years.

\section{Table 4. Case 2: Single Installation of Multi-Objective Detention System}

\begin{tabular}{|c|c|c|c|c|c|}
\hline $\begin{array}{l}\text { Return } \\
\text { Period } \\
\text { (year) }\end{array}$ & $\begin{array}{l}\text { Dura } \\
\text { tion } \\
(\min \\
\text { ) }\end{array}$ & $\begin{array}{l}\text { Precipita } \\
\text { tion } \\
(\mathrm{mm})\end{array}$ & $\begin{array}{r}\text { Peak } \\
\text { Flooding } \\
(\mathrm{CMS})\end{array}$ & $\begin{array}{l}\text { Over } \\
\text { flow } \\
\left(\mathrm{m}^{3}\right)\end{array}$ & $\begin{array}{c}\text { Surface } \\
\text { runoff } \\
\left(\mathrm{m}^{3}\right)\end{array}$ \\
\hline \multirow[t]{3}{*}{10} & 60 & 77.2 & 1.93 & 969 & 179,350 \\
\hline & 120 & 112.3 & 1.37 & 992 & 293,060 \\
\hline & 180 & 142.2 & 1.071 & 1,137 & 393,080 \\
\hline \multirow[t]{3}{*}{20} & 60 & 88.0 & 31.04 & 4,574 & 219,100 \\
\hline & 120 & 128.4 & 20.31 & 7,314 & 354,930 \\
\hline & 180 & 163.7 & 22.00 & 9,317 & 476,000 \\
\hline \multirow[t]{3}{*}{30} & 60 & 94.3 & 43.83 & $\begin{array}{l}17,94 \\
1\end{array}$ & 242,640 \\
\hline & 120 & 137.6 & 41.73 & $\begin{array}{l}25,35 \\
0\end{array}$ & 390,430 \\
\hline & 180 & 176.1 & 33.29 & $\begin{array}{l}32,28 \\
0\end{array}$ & 523,910 \\
\hline \multirow[t]{3}{*}{50} & 60 & 102.0 & 45.60 & $\begin{array}{l}35,78 \\
2\end{array}$ & 271,610 \\
\hline & 120 & 149.1 & 44.81 & $\begin{array}{l}50,88 \\
1\end{array}$ & 434,750 \\
\hline & 180 & 191.5 & 43.49 & $\begin{array}{l}64,63 \\
4\end{array}$ & 583,620 \\
\hline
\end{tabular}

After installing 1 rainwater detention system in research target basin for each preliminary selected area possible of actual installation, the flood dissolution effect on rainfall with duration of 180 minutes at 30 years and 50 years were compared and analyzed.

When rainfall occurs at a duration of 180 minutes at 30 years frequency, the rainfall dissolution effect per each rainfall detention system is shown in Figure 3. It was identified that $76.55 \%$ is resolved when installing rainwater detention system at $45,000 \mathrm{~m}^{3}$ in the same point (IC4870) and flood dissolution effect when rainfall occurs at a duration of 180 minutes at 50 years frequency.

For flood dissolution, it can be one method of designing by raising the height of rainwater detention system of the limited land area, but this research attempts for the optimal design of rainwater detention system under the premise of considering average eight of $5 \mathrm{~m}$ and the actual land area.

The equation that calculated the relationship between capacity and flood area of rainwater detention system is to calculate the flood damage amount, which is one of the benefits in linear programming, and the calculation method about each point is as follows. The flood area per capacity of detention system is shown on Figure 4- 8.

$$
\begin{aligned}
& A_{1}=3 \mathrm{E}-07 X_{1}^{2}-0.0207 X_{1}+161400 \\
& A_{2}=-4 \mathrm{E}-06 X_{2}^{2}-0.2181 X_{2}+161251 \\
& A_{3}=-6 \mathrm{E}-06 X_{3}^{2}-0.0649 X_{3}+161504
\end{aligned}
$$




$$
\begin{aligned}
& A_{4}=0.0006 X_{4}^{2}-6.2314 X_{4}+158386 \\
& A_{5}=8 \mathrm{E}-05 X_{5}^{2}-6.1984 X_{5}+139744
\end{aligned}
$$

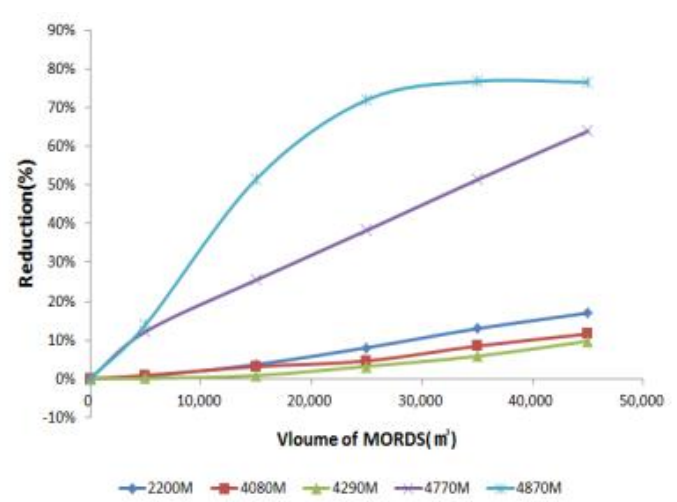

Figure 3. Overflow Reduction Effect per $\mathbf{3 0}$ year Return Periods

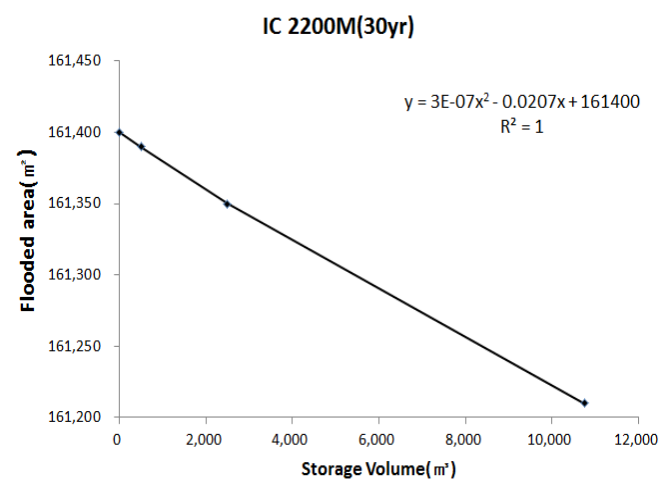

Figure 4. Flooded Area of IC2200M (30year-180min)

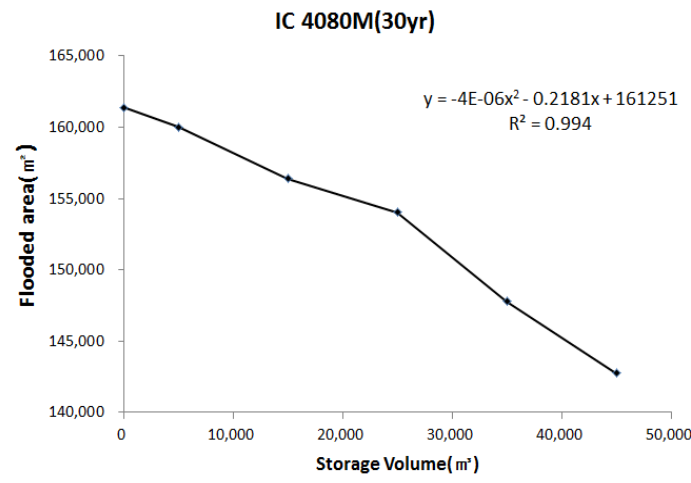

Figure 5. Flooded Area of IC4080M (30year-180min) 


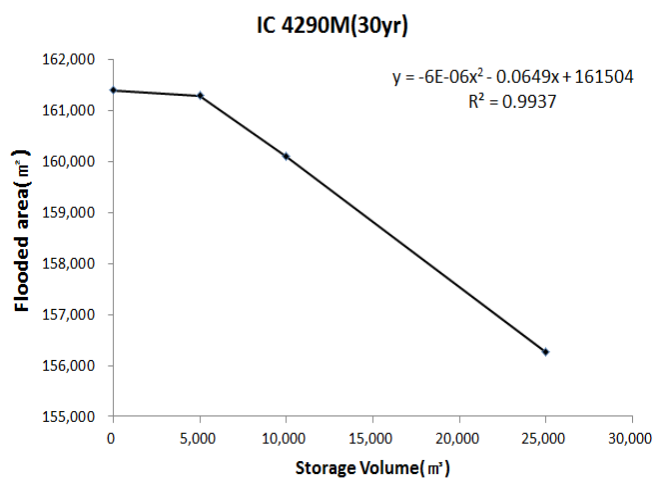

Figure 6. Flooded Area of IC4290M (30year-180min)

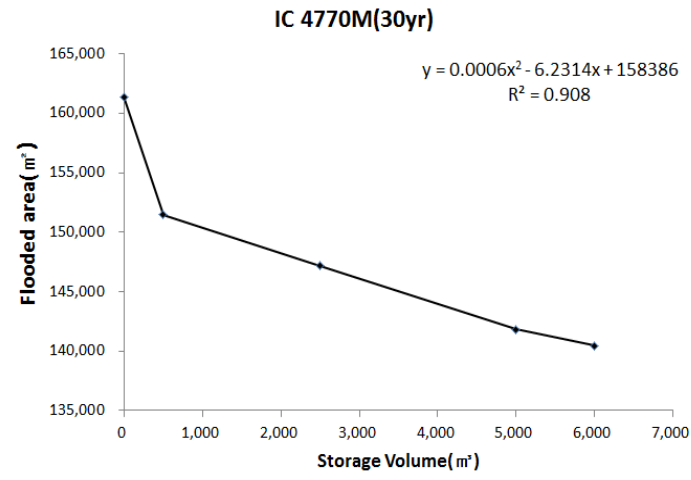

Figure 7. Flooded Area of IC4770M (30year-180min)

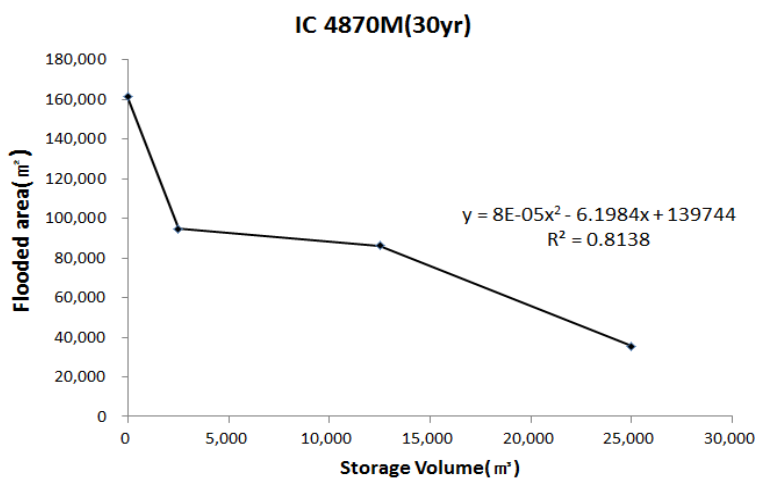

Figure 8. Flooded Area of IC4870M (30year-180min)

Flood dissolution effect per capacity of rainwater detention system at frequency of 50 years identified node number in the order of $4290 \mathrm{M}<4080 \mathrm{M}<2200 \mathrm{M}<4770 \mathrm{M}<$ 4870M. Many floods occur in the lower basin, which is the lowland according to the geological characteristic of the research target basin. When installing $45,000 \mathrm{~m}^{3}$ rainwater detention system at low basin of $4870 \mathrm{M}$, the flooding amount rapidly reduces from $32,280 \mathrm{~m}^{3}$ to $7,074 \mathrm{~m}^{3}$ where the flood dissolution effect identified to be $56.69 \%$.

The result of calculating flood area by capacity of rainwater detention system in the corresponding rainfall is shown in the following equation, and the equation of calculating the relationship between capacity and flood area of rainwater detention system is to calculate the flood damage amount, which is one of the benefits of linear programming. 
Thus, the calculation equation on each point is as follows, and the effect of the flood dissolution is shown Figure 10- Figure 14

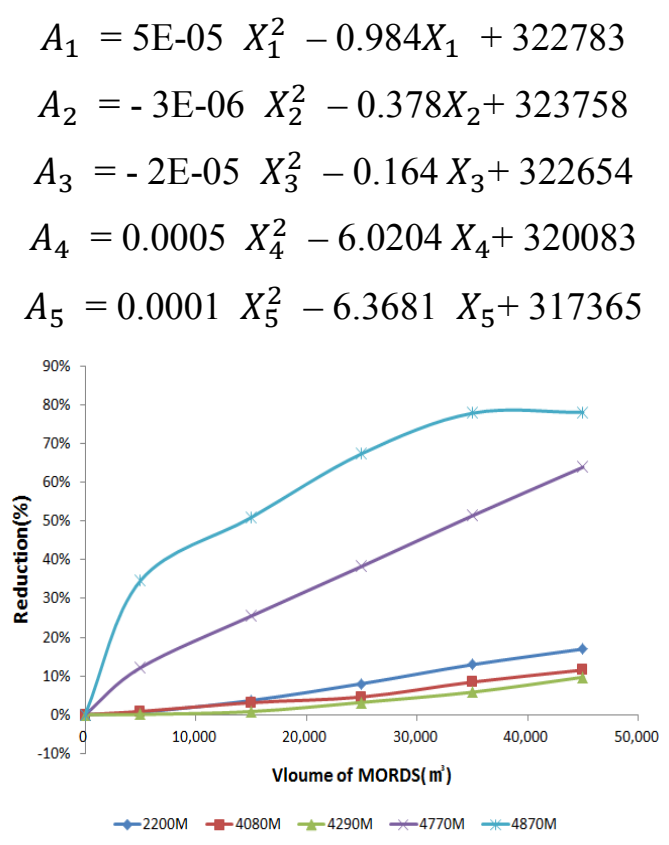

Figure 9. Overflow Reduction Effect per 50 year Return Periods

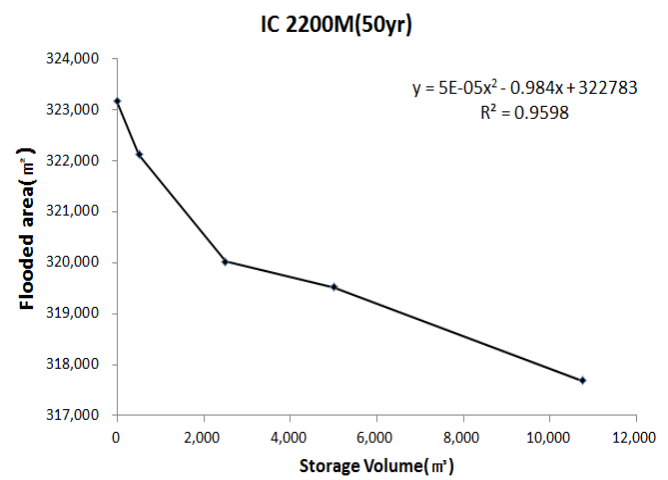

Figure 10. Flooded Area of IC2200M (30year-180min)

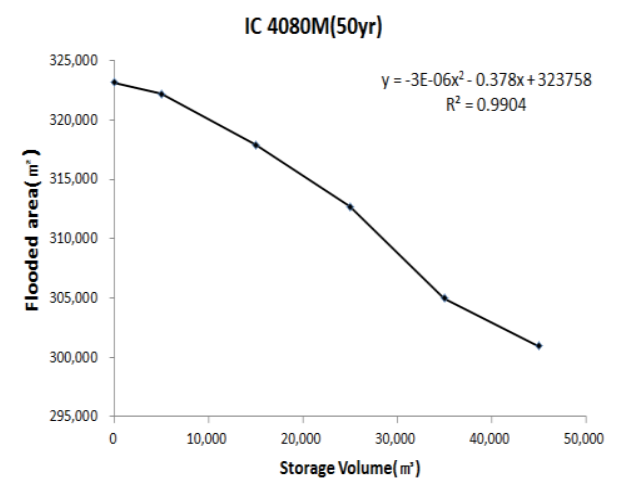

Figure 11. Flooded Area of IC4080M (30year-180min) 


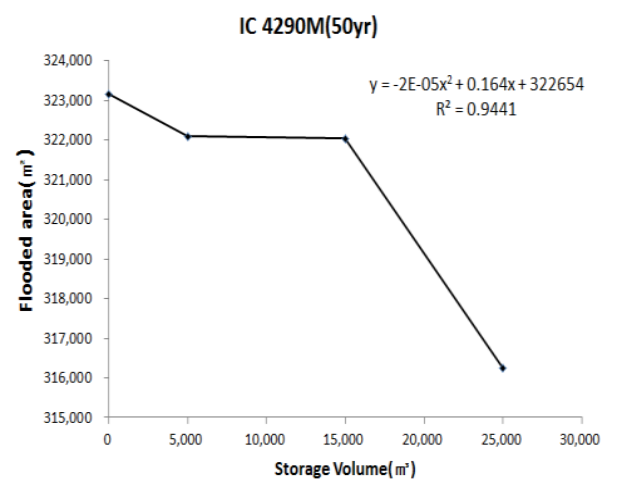

Figure 12. Flooded Area of IC4290M (30year-180min)

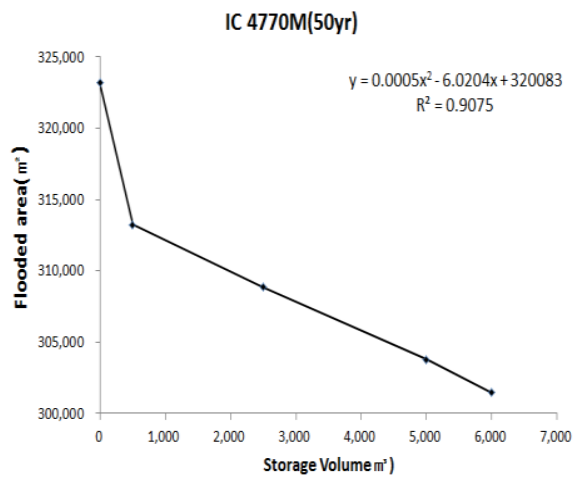

Figure 13. Flooded Area of IC4770M (30year-180min)

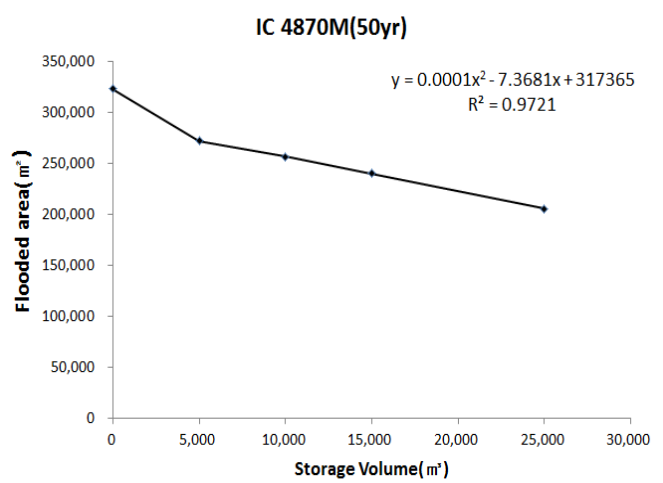

Figure 14. Flooded Area of IC4870M (30year-180min)

\subsection{Optimal Design of Multi-Objective Rainwater Detention System Using Linear Programming}

This research shall consider the cost and benefit consumed when installing multiobjective rainwater detention system in establishing linear programming of optimal design of multi-objective rainwater detention system. The cost of multi-objective rainwater detention system includes maintenance/management fee and construction fee, and the system capacity that considers cost reduction fee related to dam, flood damage amount, and water and sewage cost reduction shall be reviewed for benefit.

Also, conditions are accompanied to obtain the goal value in the linear programming where the linear programming was established as the following on 30 years and 50 years frequency by considering that the sum of all capacities of multi-objective rainwater 
detention system, limitation range of system height, and land area of multi-objective rainwater detention system shall be greater than or same as the occurred flooding amount

(1) Optimal Design of Multi-Objective Rainwater Detention System (30 Years 180 Minutes)

When the duration is 180 minutes to 30 years frequency, the following linear programming for optimal design of rainwater detention system is as follows.

$$
\text { Min Cost }=\mathrm{C}_{1}+\mathrm{C}_{2}-\mathrm{C}_{5^{-}} \mathrm{C}_{6}-\mathrm{C}_{7}
$$

Subject to

$$
\begin{gathered}
\mathrm{C}_{1}=1334.63 \mathrm{X}_{1}+805.53 \mathrm{X}_{2}+986.79 \mathrm{X}_{3} \\
+869.51 \mathrm{X}_{4}+986.79 \mathrm{X}_{5} \\
\mathrm{C}_{2}=47.08 \mathrm{X}_{1}+35.13 \mathrm{X}_{2}+39.23 \mathrm{X}_{3} \\
+44.85 \mathrm{X}_{4}+39.23 \mathrm{X}_{5} \\
\mathrm{C}_{5}=79.41 \mathrm{X}_{1}+79.41 \mathrm{X}_{2}+79.41 \mathrm{X}_{3} \\
+79.41 \mathrm{X}_{4}+79.41 \mathrm{X}_{5} \\
\mathrm{C}_{6}=6.16 \mathrm{~A}_{1}+6.16 \mathrm{~A}_{2}+6.16 \mathrm{~A}_{3}+6.16 \mathrm{~A}_{4}+6.16 \mathrm{~A}_{5} \\
\mathrm{C}_{7}=0.09 \mathrm{X}_{1}+0.09 \mathrm{X}_{2}+0.09 \mathrm{X}_{3}+0.096 \mathrm{X}_{4}+0.09 \mathrm{X}_{5} \\
32280<=\mathrm{X}_{1}+\mathrm{X}_{2}+\mathrm{X}_{3}+\mathrm{X}_{4}+\mathrm{X}_{5} \\
\mathrm{X}_{1}<=10,750 \\
\mathrm{X}_{2}<=45,000 \\
\mathrm{X}_{3}<=25,000 \\
\mathrm{X}_{4}<=6,000 \\
\mathrm{X}_{5}<=25,000 \\
\mathrm{~A}_{5}=8 \mathrm{E}-05 \mathrm{X}_{5}^{2}-6.1984 \mathrm{X}_{5}+139,744 \\
\mathrm{~A}_{4}=0.0006 X_{4}^{2}-6.2314 \mathrm{X}_{4}+158,386 \\
\mathrm{~A}_{3}=-6 \mathrm{E}-06 \mathrm{X}_{2}, 0<=\mathrm{X}_{3}, 0<=\mathrm{X}_{4}, 0<=\mathrm{X}_{5}, \\
\mathrm{~A}_{1}=3 \mathrm{E}-07 \quad X_{1}^{2}-0.0207 \mathrm{X}_{1}+161,400
\end{gathered}
$$

Here,

Cost : Total cost of multi-purpose rainwater detention system (\$)

$\mathrm{X}_{1} \sim \mathrm{X}_{5}$ : System capacity of multi-purpose rainwater detention system $\left(\mathrm{m}^{3}\right)$

$\mathrm{C}_{1}$ : Construction fee of multi-purpose rainwater detention system $\left(\$ / \mathrm{m}^{3}\right)$

$\mathrm{C}_{2}$ : Maintenance and management fee of multi-purpose rainwater detention system $(\$ /$ $\left.m^{3}\right)$ 
$\mathrm{C}_{5}$ : Water and sewage cost reduction fee $\left(\$ / \mathrm{m}^{3}\right)$

$\mathrm{C}_{6}$ : Flood damage amount $\left(\$ / \mathrm{m}^{3}\right)$

$\mathrm{C}_{7}$ : Support reduction fee related to dam $\left(\$ / \mathrm{m}^{3}\right)$

$\mathrm{A}_{1} \sim \mathrm{A}_{5}:$ Flooded area $\left(\mathrm{m}^{2}\right)$

As a result of applying the linear programming organized as above to the LINGO 14.0 Program, the maximum capacity of multi-purpose rainwater detention system was derived as $32,280 \mathrm{~m}^{3}$ in the node number point IC4080M. To verify the optimal solution, multipurpose rainwater detention system of off-line form was installed at IC4080M point at SWMM Model. The result showed that flood dissolution effect was $8.1 \%$ where there was barely any effect in installing rainwater detention system, and the flood dissolution effect in contract to the cost was $0.136 \mathrm{~m}^{3} / \$$.

Despite the installation of multi-purpose rainwater detention system in the preliminary selected area that was possible of installing rainwater detention system within the research target basin, there was barely any difference of flooding amount within the basin because not enough flooding amount occurred to dissolute the flood in the location of the installed rainwater detention system.

Therefore, this research considered the land area in IC4870M at the bottom point of the lower basin where more flood occurred, adjusted $25,000 \mathrm{~m}^{3}$ of multi-objective rainwater detention system, and executed linear programming. As a result, installing 7,280 $\mathrm{m}^{3}$ capacity of multi-objective rainwater detention system in the nearby areas of IC4080M was derived as the optimal solution. Thus the capacity of multi-objective rainwater detention system connected to node numbers IC4870M and IC4080M installed 25,000 $\mathrm{m}^{3}$ and $7,280 \mathrm{~m}^{3}$, respectively. As a result, the flooding amount decreased from $33,287 \mathrm{~m}^{3}$ to $9,013 \mathrm{~m}^{3}$, and the flood dissolution effect according to this was $72.9 \%$ while the flood dissolution effect in contrast to the cost was $0.969 \mathrm{~m}^{3} / \$$.

(2) Optimal Design of Multi-Objective Rainwater Detention System (50 Years, 180 Minutes)

When the duration is 180 minutes at 50 years, the linear programming for optimal design of multi-objective rainwater detention system is as follows. The flood damage area equation and system capacity were modified from the linear programming of 30 years suggested before to establish the following linear programming.

$$
\text { Min Cost }=\mathrm{C}_{1}+\mathrm{C}_{2}-\mathrm{C}_{5^{-}}-\mathrm{C}_{6}-\mathrm{C}_{7}
$$

Subject to

$$
\begin{aligned}
& \mathrm{C}_{1}=1334.63 \mathrm{X}_{1}+805.53 \mathrm{X}_{2}+986.79 \mathrm{X}_{3} \\
& +869.51 X_{4}+986.79 X_{5} \\
& \mathrm{C}_{2}=47.08 \mathrm{X}_{1}+35.13 \mathrm{X}_{2}+39.23 \mathrm{X}_{3} \\
& +44.85 \mathrm{X}_{4}+39.23 \mathrm{X}_{5} \\
& \mathrm{C}_{5}=79.41 \mathrm{X}_{1}+79.41 \mathrm{X}_{2}+79.41 \mathrm{X}_{3} \\
& +79.41 \mathrm{X}_{4}+79.41 \mathrm{X}_{5} \\
& \mathrm{C}_{6}=6.16 \mathrm{~A}_{1}+6.16 \mathrm{~A}_{2}+6.16 \mathrm{~A}_{3}+6.16 \mathrm{~A}_{4}+6.16 \mathrm{~A}_{5} \\
& \mathrm{C}_{7}=0.09 \mathrm{X}_{1}+0.09 \mathrm{X}_{2}+0.09 \mathrm{X}_{3}+0.096 \mathrm{X}_{4}+0.09 \mathrm{X}_{5}
\end{aligned}
$$




$$
\begin{gathered}
64,634<=\mathrm{X}_{1}+\mathrm{X}_{2}+\mathrm{X}_{3}+\mathrm{X}_{4}+\mathrm{X}_{5} \\
\mathrm{X}_{1}<=10,750 \text { (Land area height) } \\
\mathrm{X}_{2}<=45,000 \\
\mathrm{X}_{3}<=25,000 \\
\mathrm{X}_{4}<=6,000 \\
\mathrm{X}_{5}<=25,000 \\
\mathrm{~A}_{1}=5 \mathrm{E}-05 \mathrm{X}_{1}^{2}-0.984 \mathrm{X}_{1}+322,783 \\
\mathrm{~A}_{2}=-3 \mathrm{E}-06 \mathrm{X}_{2}^{2}-0.378 \mathrm{X}_{2}+323,758 \\
\mathrm{~A}_{3}=-2 \mathrm{E}-05 X_{3}^{2}-0.164 \mathrm{X}_{3}+322,654 \\
\mathrm{~A}_{4}=0.0005 X_{4}^{2}-6.0204 \mathrm{X}_{4}+320,083 \\
\mathrm{~A}_{5}=0.0001 \mathrm{X}_{5}^{2}-7.3681 \mathrm{X}_{5}+317,365 \\
0<=\mathrm{X}_{1}, 0<=\mathrm{X}_{2}, 0<=\mathrm{X}_{3}, 0<=\mathrm{X}_{4}, 0<=\mathrm{X}_{5},
\end{gathered}
$$

Here,

Cost : Total cost of multi-purpose rainwater detention system $(\$)$

$\mathrm{X}_{1} \sim \mathrm{X}_{5}$ : System capacity of multi-purpose rainwater detention system $\left(\mathrm{m}^{3}\right)$

$\mathrm{C}_{1}$ : Construction fee of multi-purpose rainwater detention system $\left(\$ / \mathrm{m}^{3}\right)$

$\mathrm{C}_{2}$ : Maintenance and management fee of multi-purpose rainwater detention $\operatorname{system}\left(\$ / \mathrm{m}^{3}\right)$

$\mathrm{C}_{5}$ : Water and sewage cost reduction fee $\left(\$ / \mathrm{m}^{3}\right)$

$\mathrm{C}_{6}$ : Flood damage amount $\left(\$ / \mathrm{m}^{3}\right)$

$\mathrm{C}_{7}$ : Support reduction fee related to dam $\left(\$ / \mathrm{m}^{3}\right)$

$\mathrm{A}_{1} \sim \mathrm{A}_{5}:$ Flooded area $\left(\mathrm{m}^{2}\right)$

As a result of executing the established linear programming, the optimal solution was suggested as installing $45,000 \mathrm{~m}^{3}, 13,634 \mathrm{~m}^{3}$, and $6,000 \mathrm{~m}^{3}$ rainwater detention system nearby IC4080M, IC4290M, and IC4770M.

Same as the 30 years frequency, as a result of stimulating as SWMM Model, the flooding amount reduced from $64,634 \mathrm{~m}^{3}$ to $53,385 \mathrm{~m}^{3}$, which appeared as $17.4 \%$. Despite installing the multi-objective rainwater detention facility as $64,634 \mathrm{~m}^{3}$, flooding amount of IC4870M located in the bottom point of the lower basin could not be controlled. Therefore, this research considered the land area in IC4870M same as the 30 years frequency to install $25,000 \mathrm{~m}^{3}$ rainwater detention system. As a result, the flood dissolution effect was $43.4 \%$, and the flood dissolution effect in contrast to cost was 0.627 $\mathrm{m}^{3} / \$$.

\section{Conclusion}


The purpose of this research was to make optimal design on capacity and number of multi-objective rainwater detention system that can satisfy irrigation and dimension of flood prevention as well as acquiring water source such as fire water, landscape water, and water for living in the medium and small scale basin where flood occurs frequently during focused raining due to the increase of impermeability layer.

To execute this purpose, (1) preliminary selected area of multi-objective rainwater detention system using SWMM Model was selected; (2) scenario that considered location and number of multi-objective rainwater detention system was analyzed; (3) optimal design of multi-objective rainwater detention system that becomes minimum cost and maximum benefit using linear programming was attempted; (4) and application and verification to actual rainfall were executed. The results are as follows.

1) As a result of comparing and analyzing the discharge amount and flooding amount per scenario after considering location, capacity, and number of rainwater detention system at 30 and 50 years in duration of 180 minutes where the most flooding amount occurred, the flood dissolution effect at downstream bottom point at 30 years and 50 years frequency when installing 1 rainwater detention system per each location was $76 \%$ and $57 \%$, respectively.

2) For 10 20 years frequency at 10, 20,30 and 50 years frequencies, the flooding amount due to rainfall discharge was smaller than the installation capacity of rainwater detention system, where it was judge to be inappropriate in the utilization of rainwater detention system.

3) The methodology executed in this research was designed so that the construction fee and maintenance/management fee consumed in the rainwater detention system become minimized while various benefits including water and sewage cost, dam construction fee reduction, and flood damage cost reduction fee can be maximized. When considering the installation of rainwater detention system in the already developed cities or new cities, more effective design can be possible when using the same method.

\section{Acknowledgements}

This subject is supported by Korea Ministry of Environment as "Projects for Developing Eco-Innovation Technologies (GT-11-G-02-001-1)".

\section{References}

[1] A. Massoudieh, P.K. Behera and M.T. Le, "Evaluating the Performance of Low Impact Developments on Runoff Volume in Washington DC", Columbia University final report (2012).

[2] H. Jia, Y. Lu, S.L. Yu and Y. Chen, "Planning of LID-BMPs for urban runoff control", The case of Beijing Olympic Village”, Separation and Purification Technology 84 pp. 112-119 (2012).

[3] R.E. Horton, "The role of infiltration in the hydrologic cycle", Transactions, American Geophysical Union 14: pp.446-460 (1933).

[4] W.C. Huber and R.E. Dickinson, "Storm Water Management Mode", ver4:User's Manual, U.S. EPA (1988).

[5] PGC: Department of Environmental Resources, "Low-Impact Development Design Manual", Prince George's County (1997). 